\title{
DAMPAK PERGAULAN BEBAS SEBAGAI SUMBER IDE PENCIPTAAN KRIYA SENI
}

\author{
Oleh: \\ I Wayan Arissusila \\ Fakultas Pendidikan Agama dan seni UNHI Denpasar \\ Email: fpasunhi@gmail.com
}

\begin{abstract}
Humans are God's creatures, who live according to their respective abilities. There are human lives prefer the pleasure, enjoyment and luxury. In life looks like a good meal, luxurious clothing and visible among adolescents tend to lead to sex. Adolescence is the age, studying opportunities and positive nature. In fact, many carried out by mutually couple, without thinking about the future and health. Such behavior is most likely caused by promiscuity impact of AIDS on the body including the organs that are inside, resulting in death. In this paper, the problem can be posed: how do mentranspormasi theme, the impact of free associations as the source of the idea of creathing art craft. By using the methods associated with the stages of the creations of works of art. Used to dissect the problems that relepan theory with the creation of works of art. The result can be aware of the imfact of free association as a source of ideas in the creation of craft art, threedimensional shaped and finished to use transparent watercolors.
\end{abstract}

Keywords: The Impact Of Free Association, Humans Organs, HIV, and Kriya Art.

\begin{abstract}
Abstrak
Manusia merupakan makhluk ciptaan Tuhan, yang menjalani hidup sesuai dengan kemampuannya masing-masing. Ada manusia menjalani hidup lebih mengutamakan kesenangan, kenikmatan dan kemewahan. Dalam kehidupan terlihat seperti makan enak, pakaian serba mewah dan terlihat dikalangan remaja cenderung mengarah pada seksual. Masa remaja merupakan usia produktif, kesempatan menuntut ilmu dan sifatnya positif. Kenyataannya, banyak dilakukan dengan gonta-ganti pasangan, tanpa memikirkan masa depan dan kesehatan. Prilaku demikian kemungkinan besar disebabkan karena pergaulan bebas yang berdampak penyakit AIDS pada tubuh termasuk organorgan yang ada di dalamnya, mengakibatkan kematian. Dalam makalah ini, permasalahannya dapat diajukan yakni bagaimana caranya mentranspormasi tema, dampak pergaulan bebas sebagai sumber ide penciptaan kriya seni. Dengan menggunakan metode yang berkaitan dengan tahapan-tahapan terciptanya karya seni. Untuk membedah permasalahan digunakan teori yang relepan dengan terciptanya karya seni. Hasilnya dapat mengetahui tentang dampak pergaulan bebas sebagai sumber ide dalam penciptaan kriya seni, yang berbentuk tiga dimensional dan difinishing menggunakan cat air secara transparan.
\end{abstract}

Kata kunci: Dampak Pergaulan Bebas, Organ Tubuh Manusia, HIV dan Kriya Seni.

\section{PENDAHULUAN}

Manusia merupakan makhluk hidup ciptaan Tuhan yang paling tinggi derajatnya dibanding- kan dengan makhluk lain, karena memiliki akal dan budi. Manusia yang ada di dunia ini menjalani hidup sesuai dengan kemampuannya masing-masing. Ada pula menjalani hidup mengu- 
tamakan kesenangan, kenikmatan dan kemewahan. Seperti misalnya makan enak, pakaian serba mewah, kendaraan sering di ganti dengan model terbaru dan termahal. Begitu juga dalam perawatan wajah, dimana bentuk hidung yang dianggap kurang serasi diperbaiki melalui bedah plastik. Tempat hiburan misalnya kave, diskotik di kota-kota besar seperti Surabaya dan Jakarta, padat dikunjungi orang-orang yang senang dalam hal tersebut. Terlihat pula dikalangan remaja yang cenderung mengarah pada seksual. Masa remaja merupakan usia produktif, kesempatan menuntut ilmu dan sifatnya positif. Tetapi kenyataannya banyak dilakukan dengan bergantian, tanpa memikirkan masa depan. Sebagaian besar disebabkan karena adanya pergaulan yang tidak terkontrol yaitu pergaulan bebas berdampak penyakit AIDS pada tubuhnya dan organ-organ yang ada di dalamnya.

Organ tubuh manusia mempunyai fungsi tertentu dan secara visual mengandung bentuk artistik yang berbeda antara satu dengan yang lainnya. Tetapi tetap menjadi satu kesatuan dalam tubuh manusia yang dapat dilihat dari ujung kaki sampai ujung rambut yang kesemuanya diperlukan tubuh. Dengan bersatunya keseluruhan organ tubuh ini, manusia dapat berpikir, berbicara dan berjalan. Organ adalah dua jaringan atau lebih yang bergabung membentuk satu organ seperti perut, ginjal, mata dan lainnya (Setiadi, 2007: 3). Selanjutnya, jaringan adalah sekelompok sel dengan struktur yang sama dan melakukan fungsi yang sama. Adapun jaringan tersebut yaitu: jaringan pengikat, efitel, otot dan jaringan saraf. Keempat jaringan ini sangat diperlukan tubuh manusia untuk penggerak pada tubuh, merespon apabila ada perubahan lingkungan seperti panas, dingin dan lain-lain. Sistem organ adalah gabungan beberapa organ yang bekerja sama untuk melakukan fungsi yang saling berkaitan. Sistem organ atau susunan tubuh juga penting pada tubuh manusia. Di mana susunan tubuh ada sepuluh jenis yaitu: sitem pencernaan, pernapasan, ekskresi, peredaran darah (transportasi), rangka, otot, endokrin, saraf, reproduksi dan pancaindra.

Manusia beserta organ tubuh perlu diperhatikan kesehatannya, karena dengan memperhatikan kesehatan, manusia terhindar dari berbagai penyakit. Apabila manusia tidak memperhatikan kesehatan tubuhnya sendiri akan mu- dah terkena penyakit seperti AIDS (acquired immunodeficiency syndrome). Diakibatkan oleh virus HIV (human immunodeficiency virus) (Gallant, 2010: 16). HIV ditularkan dari orang keorang lewat hubungan seksual, air mani, cairan vagina atau darah dari orang yang sudah terinfeksi harus memasuki badan orang yang belum terinfeksi. Virus HIV menyebar lewat jarum suntik yang sudah berisi virus dan menyebar keseluruh tuhuh manusia lewat darah. Kalau tidak diobati virus HIV, akan menyebabkan kerusakan semakin lama semakin parah dan mengakibatkan kematian. Diharapkan sedini mungkin untuk memperhatikan kesehatan organ tubuh sendiri, agar terhindar dari virus (HIV) yang mengakibatkan penyakit AIDS.

Ketertarikan pencipta terhadap organ tubuh manusia karena memiliki nilai keindahan dan keunikan. Keindahan terlihat pada lipatan-lipatan yang memperlihatkan bidang-bidang cekung, cembung, urat-urat meliuk-liuk sebagai aliran darah, memiliki kesan kehidupan dan mempunyai fungsi berbeda-beda. Keunikan lain terdapat bentuk keci-kecil yang rumit, menjelimet, misalnya bentuk gelembung-gelembung cairan atau jaringan menghubungkan organ satu dengan organ lain. Ketertarikan terhadap virus HIV yang menyebabkan penyakit AIDS pada tubuh manusia karena ada kesan penyakit disebabkan oleh virus dan penyaluran lewat hubungan seksual dan jarum suntik melalui darah sampai keorgan tubuh manusia. Organ tersebut di rongrong mengakibatkan organ organ lain menjadi rusak, borok dan tidak berfungsi sesuai dengan aturan tubuh manusia.

Ulasan di atas menarik untuk divisualisasikan dalam karya kriya seni. Mempersentasikan ide-ide atau mewujudkan ke dalam karya seni, simbol merupakan hal yang tepat untuk menjembati antara konsep dan karya yang diciptakan. Simbol dimunculkan dalam karya seni sangat penting seperti bentuk geometris, unsurunsur seni rupa, makhluk hidup dan yang lainnya. Simbol bisa pula dimunculkan dalam pemikiran kreatif, dengan cara perenungan dan meditasi. Untuk itu diangkat bentuk organ tubuh manusia dan virus HIV yang menyebabkan penyakit AIDS, sebagai simbol kehidupan dan kejahatan. Dengan harapan dapat memberikan jalan representasi ide-ide yang diinginkan.

Dalam memvisualisasikan ke dalam media kayu, bahan yang dipergunakan yakni, kayu jati, 
sonokeling dan kayu suwar menggunakan teknik ukir, konstruksi dan craftmenshif yang tinggi. Organ tubuh manusia terinfeksi HIV dirubah sesuai dengan keinginan pencipta. Serta masing-masing dari bahan diolah dan dipadukan sedemikian rupa, agar aksentuasi yang unik dan indah terlihat dalam karya. Dengan demikian dihasilkan karya seni original sebagai cerminan identitas pribadi pencipta.

\section{Kajian Sumber Penciptaan}

Untuk tersusunya hasil penciptaan yang lebih sempurna, diperlukan pula kajian sumber yang dijadikan inspirasi penciptaan. Dalam hal ini ada beberapa sumber yang perlu dan penting untuk dikaji yaitu: reperensi yang berkaitan dengan judul yang diangkat dan berkaitan dengan karya yang diciptakan. Adapun kajian sumber yang dimaksud adalah:

\section{Sumber Tertulis}

\section{A. Tinjauan Pergaulan bebas}

Pergaulan merupakan suatu hal yang penting dalam kehidupan manusia. Dengan adanya pergaulan akan membawa perubahan besar terhadap manusia itu sendiri. Baik itu perubahan positif maupun negatif tergantung manusia dalam bergaul. Bergaul dengan orang-orang baik akan berdampak baik terhadap dirinya. Bergaul dengan orang-orang tidak baik atau pergaulan bebas berdampak tidak baik dan bisa merugikan diri sendiri. Pergaulan lebih banyak terlihat dikalangan remaja, cenderung mengarah pada kesenangan, kenikmatan dan kemewahan. Seperti misalnya makan enak, pakaian serba mewah, kendaraan sering di ganti dengan model terbaru dan termahal. Begitu juga dalam perawatan wajah, dimana bentuk hidung yang dianggap kurang serasi diperbaiki melalui bedah plastik. Rambut orang Indonesia yang dulunya hitam kini banyak dicat berbagai warna. Tempat hiburan misalnya kave, diskotik di kotakota besar seperti Surabaya, Bandung dan Jakarta, padat dikunjungi oleh orang-orang yang senang dalam hal tersebut. Terlihat pula dikalangan remaja cenderung mengarah pada seksual. Masa remaja merupakan usia produktif, kesempatan menuntut ilmu dan sifatnya positif. Tetapi kenyataannya banyak dilakukan dengan bergantian, tanpa memikirkan masa depan. Sebagian besar disebabkan karena adanya per- gaulan yang tidak terkontrol yaitu pergaulan bebas berdampak penyakit AIDS pada tubuh termasuk organ-organ di dalamnya yang dapat mengakibatkan kematian.

\section{B. Tinjauan Organ Tubuh Manusia}

Manusia merupakan makhluk ciptaan tuhan yang memiliki akal dan berbadan. Badannya bersatu dengan realitas sekitarnya dengan demikian, manusia bangkit berada dalam suatu cahaya, mampu melihat dirinya, barang-barang disekeliling, menempatkan diri, mengerti sini dan sana, bisa berjalan, berbicara, mengambil sesuatu dan sebagainya. Dalam badan manusia terdapat dua kemampuan yang disebut dengan kemampuan rohani dan jasmani yang bersatu dalam diri manusia. Kemampuan rohani adalah tidak seperti barang-barang lainnya, tidak terbentang, tidak terlipat-lipat. Kemampuan itu bisa menyebabkan berdiri sendiri, bisa menghadapi diri dan barang lain. Sedangkan jasmani artinya materi. Dia berat atau ringan, berdarah, berdaging, bisa dilihat secara anatomis, mirip dengan makhluk-makhluk lainnya (Drijarkara, 1990: 10-11). Jadi keseluruhan badan manusia itu adalah kesatuan rohani dan jasmani yang tidak bisa dipisahkan. Termasuk organ-organ yang ada dalam tubuh manusia yang sangat diperlukan dan dibutuhkan kemampuan rohani oleh tubuh atau organ-organnya untuk menggerakkan dan menghidupkan sehingga berfungsi sesuai dengan aturan tubuh manusia.

Organ mempunyai pengertian yaitu dua jaringan atau lebih yang bergabung membentuk satu organ seperti perut, ginjal, mata dan lainnya (Setiadi, 2007: 3). Sedangkan tubuh adalah: keseluruhan jasad manusia atau binatang yang kelihatan dari bagian ujung kaki sampai keujung rambut (Fajri. Ratu Aprilia Senja, tt: 831). Semuanya itu menjadi satu tetapi mempunyai tugas, atau fungsi yang berbeda beda dalam tubuh manusia. Adanya jaringan yang berbeda-beda, maka masing-masing jaringan mempunyai fungsi dan bentuk yang berbeda-beda pula. Jaringan-jaringan ini ada yang berfungsi untuk melindungi organ yang lemah atau untuk mempersatukan organ satu dengan organ yang lainnya, berfungsi untuk melakukan suatu pergerakan dibeberapa tubuh, misalnya pada jantung atau pada tulang. Ada juga yang berfungsi untuk merespon suatu perubahan dari lingkungan sekitar, biasanya jaringan ini terdapat diotak 
yang disebut dengan jaringan saraf dan yang lainnya. Dalam karya kriya seni yang pencipta buat, jaringan itu tidak ada, yang dibuat sebagai pemisah organ satu dengan organ yang lainnya yaitu bentuk lekukan-lekukan, baik itu cekung, cembung atau gelembung-gelembung yang diibaratkan sebagai darah dan bentuk lekukan-lekukan baik itu cekung, cembung dan berupa kulit sebagai penutup organ-organ tersebut.

Selain organ dan jaringan ada pula sistem organ yang ada dalam tubuh manusia. Sistem organ mempunyai fungsi dan kegunaan yang berbeda-beda antara satu dengan yang lainnya. Apabilah dilihat dari segi namanya juga berlainan, ada yang bernama sistem transportasi, sistem rangka dan sebagainya. Dilihat dari segi ukuran, warna dan bentuknya juga berlaian. Jadi sistem organ yang ada pada tubuh manusia baik yang di dalam maupun di luar tubuh, cukup banyak dan sangat penting. Untuk lebih jelasnya dapat dilihat pada bagian sistem organ. Sistem organ adalah gabungan beberapa organ yang bekerja sama untuk melakukan fungsi yang saling berkaitan (Setiadi, 2007: 3). Sistem organ ini ada sepuluh bagian dan terdapat pada tubuh manusia yaitu: sistem pencernaan, pernapasan, ekskresi, peredaran darah, rangka, otot, endokrin, saraf, reproduksi dan pancaindra. Kesemuanya ini mempunyai pengertian dan fungsi yang berbea-beda antara satu dengan yang lainnya, tetapi tetap menjadi satu kesatuan dalam tubuh manusia.

Dari uraian sebelumnya, ada beberapa organ tubuh manusia yang pencipta buat terkait dengan penyakit AIDS. Namun dalam sub ini lebih banyak dibahas tentang organ tubuh manusia, yang pencipta buat dalam media kayu misalnya: sistem reproduksi (penis, dan vagina).

\section{Penis (Sistem Reproduksi)}

Penis merupakan alat kelamin laki-laki. Penis termasuk sistem reproduksi, yang berfungsi untuk memasukkan sperma ke dalam tubuh perempuan dan perkembangbiakan yang nantinya berguna untuk melanjutkan keturunan. Untuk melangsungkan keturunan dalam sistem reproduksi ada dua disebut alat kelamin betina dan alat kelamin jantan. Alat kelamin jantan yaitu penis salah satunya. Penis sangat berguna bagi laki-laki, selain berfungsi untuk memasukkan sperma, juga sebagai tempat saluran kencing yang dikeluarkan dan tidak berguna bagi tubuh itu sendiri. Dalam sistem reproduksi laki-laki terdiri atas sepasang testis, saluran-saluran kelamin, kelenjar-kelenjar tambahan dan penis yang sudah dijelaskan di atas.

Pertama testis adalah organ lunak, berbentuk oval dengan panjang 4-5 cm dan diameter $2,5 \mathrm{~cm}$. Testis berfungsi untuk menghasilkan hormon testeron dan sperma. Testis terletak di dalam suatu kantong disebut skrotum. Skrotum yaitu kantong longgar yang tersusun atas kulit, fasia dan otot polos yang membungkus dan menopang testis di luar tubuh yang pada suhu optimum untuk produksi spermatozoa. Dibagian kelenjar testis ada beberapa bagian yaitu: tunika albuginea, tubulus seminiferus, duktus, epididimis dan duktus deferens (Setiadi, 2007: 92-94). Kedua saluran-saluran kelamin terdiri dari: vasa eferentia, epididimis dan vas deferens. Vas eferentia merupakan bagian yang berfungsi menampung sperma untuk disalurkan ke epididimis. Epididimis adalah saluran berkelokkelok dengan panjang 5-6 m. Saluran ini berfungsi untuk menyimpan sperma sementara selama tiga minggu. Sedangkan vas deperen yaitu saluran lurus dengan panjang $40 \mathrm{~cm}$, yang berfungsi untuk menghubungkan epididimis dengan uretra pada penis (Budiyono, 2011: 84). Ketiga Kelenjar-kelenjar tambahan terdiri dari vesika seminalis, kelenjar prostat dan kelenjar cowperi. Vesika seminalis adalah kantong semen yang dindingnya menyekresi cairan lendir yang banyak mengandung fruktosa, sedikit asam askorbat dan asam amino. Bahan-bahan kimia itu berfungsi untuk memberi makan dan melindungi sperma sebelum membuahi ovum. Kelenjar frostat yaitu kelenjar yang berbentuk bulat mengelilingi bagian pangkal saluran uretra. Kelenjar ini mengeluarkan cairan basa yang menyerupai susu menetralisir asiditas vagina selama senggama dan meningkatkan motilitas sperma (Setiadi, 2007: 96). Kelenjar ini membesar saat remaja berusia 20 tahun. Sedangkan kelenjar cowperi yaitu kelenjar berukuran butir kacang yang terletak di bagian proksimal uretra. Kelenjar ini mengeluarkan cairan mukosa berfungsi sebagai pelicin (Budiyono, 2011: 84).

Sistem reproduksi (penis) pada laki-laki berhubungan erat dengan sistem ekskresi khususnya sistem urinaria. Uretra merupakan saluran yang berfungsi untuk mengeluarkan urine sekaligus sperma. Testis memproduksi jutaan setiap hari sejak masa pubertas sampai seorang laki- 
laki meninggal. Jika tidak dikeluarkan sel-sel sperma akan mati dan diserap kembali.

\section{Vagina (Sistem Reproduksi)}

Vagina termasuk bagian dari sistem reproduksi, yang dimiliki oleh perempuan. Sistem reproduksi perempuan terdiri atas dua bagian yaitu genitalia eksterna dan genitalia interna. Kedua bagian ini sangat penting dan perlu di dalam sistem reproduksi perempuan.

Genetalia eksterna secara kesatuan disebut vulva atau pudendum yang terdiri dari: (1) Mons pubis merupakan bantalan jaringan lemak dan kulit yang terletak di atas simpisis pubis. (2) Labia mayora (bibir mayor) adalah dua lapisan kulit longitudinal yang merentang kebawah dari mons pubis dan menyatu pada sisi posterior perineum. (3) Labia minora (bibir minor) adalah lipatan kulit diantara labium mayora, tetapi mengandung kelenjar sebasea dan beberapa kelenjar keringat. (4) Klitoris terdiri dari dua krira (akar) satu batang dan satu glans klitoris bundar yang banyak mengandung ujung syaraf dan sangat sensitif. (5) Vestibula adalah area yang dikelilingi oleh labia minora yang menutupi uretra, mulut vagina dan duktus kelenjar bartholini. Kelenjar bartholini berfungsi untuk memproduksi beberapa tetes sekresi mukus untuk membantu melumasi orifisium vagina saat eksitasi vagina seksual. (6) Orifisum uretra adalah jalur keluar urine dari kandung kemih, tepi lateralnya mengandung duktus untuk kelenjar parauretral yang dianggap homolog dengan kelenjar prostat pada laki-laki. (7) $\mathrm{Mu}-$ lut vagina, terletak di bawah orifisium uretra. Himen merupakan suatu membran yang berfungsi untuk melingkari mulut vagina. (8) Perineum merupakan kulit antara pertemuan dua lipatan labia mayor dan anus yang merupakan area yang terbentang dari simpisis pubis di sisi anterior sampai ke koksiks disisi posterior dan ketuberositas iskial disisi lateral (Stiadi, 2007: 100-102).

Sedangkan genetalia interna terdiri dari (1) ovarium merupakan kelenjar kelamin perempuan yang berfungsi untuk memproduksi ovum dan menyekresi hormon estrogen dan progesteron. (2) Saluran telur berfungsi untuk menyalurkan ovum kearah rahim dengan gerakan peristaltik dan dibantu oleh gerakan silia yang terdapat di dindingnya, dengan panjang $12 \mathrm{~cm}$. (3) Uterus ( rahim) berfungsi untuk tempat berkem- bangnya embrio, dengan ukuran panjang 7,5 $\mathrm{cm}$, lebar $5 \mathrm{~cm}$, dan mampu mengembang sampai 500 kali. (4) Vagina merupakan saluran yang terletak di bawah uterus sebagai tempat bagi penis pada saat kopulasi dan sebagai tempat keluarnya bayi. Ukuran vagina berpariasi dengan panjang 8-10 cm (Budiyono, 2011: 85).

Selain itu dalam reproduksi perempuan terdapat pula hormon yang terdiri dari hormon estrogen dan progesteron. Hormon estrogen berfungsi untuk merangsang pertumbuhan semua organ reproduksi. Sedangkan hormon progesteron berfungsi untuk perkembangan kehamilan yang normal. Apabila hormon ini bertemu dengan hormon laki-laki akan terjadi pembuahan. Sebelum proses pembuahan akan terjadi beberapa proses sebagai berikut: ovum yang telah masuk akan keluar dari ovarium, selanjutnya ovum yang masak akan masuk ke saluran fallopii. Jutaan sperma harus berjalan dari vagina menuju uterus dan masuk ke saluran fallopii. Dalam perjalanan itu kebanyakan sperma dihancurkan oleh mukus. Di antara beberapa sel sperma yang bertahan hidup hanya satu yang bisa menembus membran ovum. Setelah terjadi pembuahan membran ovum segera mengeras untuk mencegah sel sperma lain masuk. Proses pembuahan ini terjadi di fallopi (Budiyono, 2011: 86). Hasil dari pembuahan ini adalah zigot yang kemudian mengalami pertumbuhan dan perkembangan hingga menjadi bayi yang dikeluarkan lewat vagina.

Jika ovum yang sudah masak apabila tidak dibuahi oleh sperma, jaringan penyusun dinding akan rusak dan luruh atau runtuh. Bersamaan dengan ovum yang tidak dibuahi, jaringan tersebut akan dikeluarkan lewat vagina yang disebut dengan menstruasi.

\section{Tinjauan HIV Dan AIDS}

Manusia sangat penting memperhatikan kesehatan tubuhnya termasuk organ yang ada di dalamnya. Dengan mengetahui kesehatan, manusia akan terhindar dari penyakit. Karena penyakit tersebut bisa disebabkan beberapa paktor yaitu: makanan, minuman, lingkungan sekeliling kotor, kurangnya istirahat, udara kotor, hubungan seksual yang sering gonta ganti pasangan dan yang lainnya. Hal ini ditekankan pada penyakit AIDS, yang disebabkan oleh virus HIV. Virus ini pertama kali ada di sub-Sahara Aprika suatu saat dalam paruh pertama dari abad ke 
dua puluh, yang ditularkan dari sipanse, mungkin ketika manusia terkena darah sipanse sewaktu berburu atau memotong-motong dagingnya. Kemudian virus HIV ini menyebar ke luar memasuki Amerika Serikat antara pertengahan dan akhir tahun 70 an, dan kini virus tersebut telah menyebar hampir keseluruh dunia (Gallant, 2010: 18-19). Misalnya Brazil, India, Thailand, Rumania, Zaire, Kamerun, Cina, Korea, Indonesia dan yang lainnya. Virus HIV tersebut tidak saja menyebar diwilayah kota, kini dilingkungan desa maupun rumah tangga pun sudah semakin banyak.

Virus HIV termasuk kelompok retrovirus, virus yang mempunyai enzim (protein) yang dapat mengubah RNA, materi genetiknya, menjadi DNA. Klompok ini disebut retrovirus karena virus ini membalik urutan normal yaitu DNA diubah (diterjemahkan) menjadi RNA. Setelah menginfeksi, RNA HIV berubah menjadi DNA oleh enzim reverse transcriptase. DNA kemudian disisipkan ke dalam DNA sel-sel manusia. DNA itu kemudian dapat digunakan untuk membuat virus baru, yang menginfeksi sel-sel baru, atau tetap tersembunyi dalam sel-sel yang hidup panjang, atau tempat penyimpanan, seperti sel-sel CD4 yang istirahat (Gallant, 2010: 16).

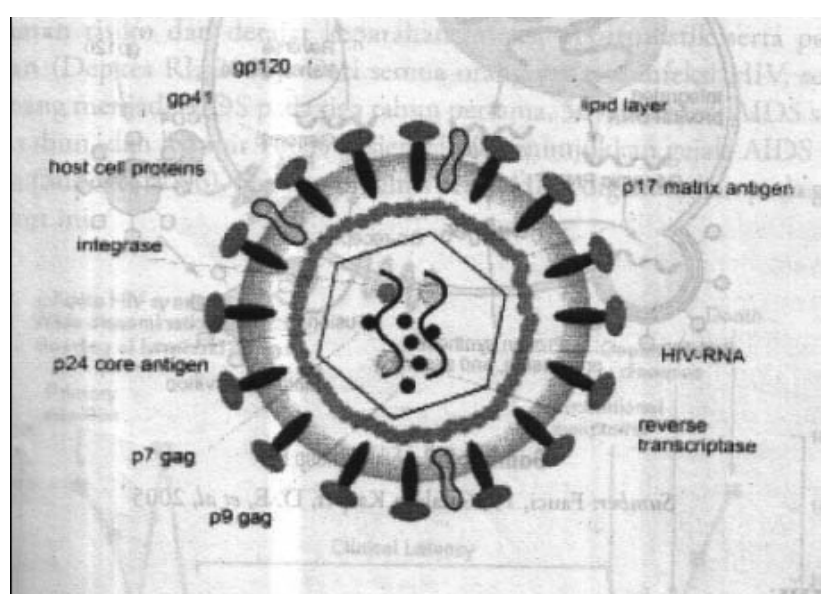

Gambar 1. Struktur Virus HIV

(Sumber: Nursalam. Ninuk Dian Kurniawati, 2007: 43)

Secara struktural morfologinya, bentuk HIV terdiri atas sebuah silinder yang dikelilingi pembungkus lemak yang melingkar. Pada pusat lingkaran terdapat untaian RNA. Selain hal tersebut HIV juga mempunyai tiga gen yang merupakan komponen fungsional dan struktural yaitu: gen gag mengode pro- tein inti. Gen pol mengode enzim reverse transcriptase, protease, dan integrase. Gen env mengode komponen struktural HIV yang dikenal dengan glikoprotein. Selain gen itu terdapat pula gen yang lainnya yaitu: rev, nef, vif, vfu, dan vpr (Nursalam, Ninuk Dian Kurniawati, 2007: 42-43).

Selain dari struktural yang telah dijelaskan di atas, HIV juga memilik siklus hidup. Dimana sel pejamu yang terinfeksi HIV memiliki waktu hidup sangat pendek, hal ini berarti HIV secara terus menerus menggunakan sel pejamu baru untuk mereplikasi diri dan setiap hari menghasilkan 10 meliar virus. Serangan pertama HIV akan tertangkap oleh sel dendrit pada membrane mukosa dan kulit pada 24 jam pertama setelah paparan. Sel yang terinfeksi tersebut akan membuat jalur ke nodus limfa dan kadang-kadang ke pembuluh darah prifer selama lima hari setelah paparan, dimana replikasi virus semakin cepat. HIV juga memiliki siklus hidup yang dapat dibagi menjadi lima yaitu: masuk dan mengikat, reverse trans kriptase, replikasi, budding, dan maturasi (Nursalam, Ninuk Dian Kurniawati, 2007: 43).

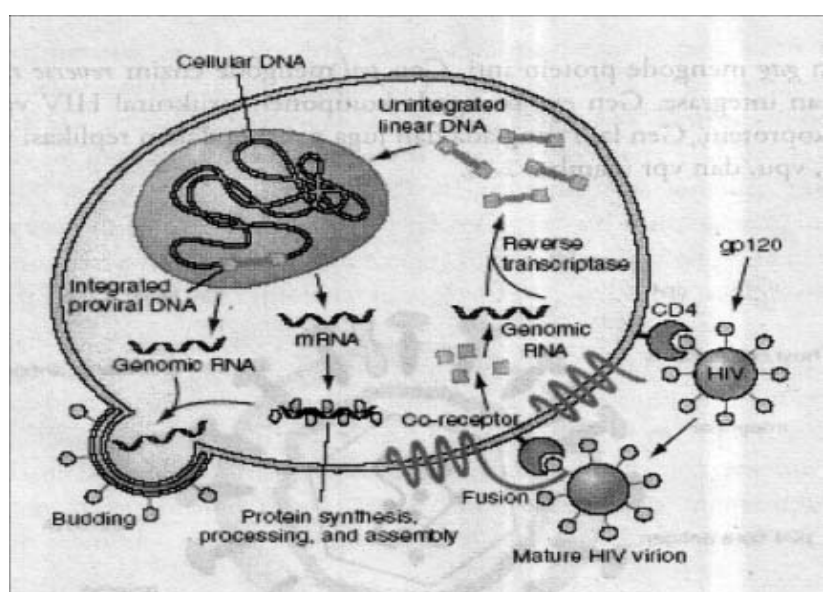

Gambar 2. Siklus hidup HIV

(Sumber: Nursalam. Ninuk Dian Kurniawati, 2007: 44)

HIV ada dua jenis yang dapat menyebabkan AIDS yaitu: HIV-1 dan HIV-2. Namun HIV-1 bermutasi lebih cepat karena reflikasinya cepat, dan jenis HIV ini yang paling umum ada di seluruh dunia. Virus HIV ini, awalnya dilaporkan menjangkit kaum laki-laki homoseksual dan biseksual, tetapi kelompok ini menyebar luas menyertakan penggunaan obat terlarang yang disuntikkan. Virus ini dapat menyebar melalui dua cara yaitu menyebar lewat seks, air mani, 
cairan vagina, atau darah dari orang yang sudah terinfeksi harus memasuki badan yang belum terinfeksi atau bisa juga lewat persalinan dan menyusui. Ada juga penyebarannya lewat alat tajam dan runcing misalnya: jarum suntik, melalui darah yang disalurkan kepada orang yang belum mengidap virus HIV, pisau, silet, menyunat seseorang, membuat tato, memotong rambut dan sebagainya yang bisa menularkan HIV sebab alat tersebut dipakai tanpa disterilkan terlebih dahulu. Sekarang ini diperkirakan bahwa lebih dari 40 juta anak-anak dan orang dewasa terinfeksi HIV di seluruh dunia (Gallant, 2010: 19).

Virus HIV ini dapat merusak kekebalan tubuh, dapat mempengaruhi penurunan berat badan, berkeringat dimalam hari, diare, dapat mempengaruhi secara langsung banyak organ badan, seperti sistem saraf, ginjal dan yang lainnya. Untuk saat ini virus HIV yang mengakibatkan penyakit AIDS belum ada obatnya. Cuma bisa mencegahannya secara langsung berkaitan dengan cara penularannya yaitu: pertama membatasi jumblah pasangan seksual. Kedua melakukan aktivitas seksual kecuali dilubang anus atau vagina. Ketiga menggunakan kondum bila berhubungan seksual, tetapi berhubungan dengan memakai kondum ini tidak bisa dipendam sampai satu hari, itu ada aturan pemakainya. Keempat tidak diperbolehkan memasukkan air mania atau cairan yang dikeluarkan venis atau vagina ke dalam mulut maupun mata. Kelima jangan mempergunakan jarum dan suntikan bersama orang lain. Keenam bila ingin mempergunakan jarum suntik bersama orang lain, itu harus dibersihkan terlebih dahulu supaya kuman hilang dan ketujuh apabila ibu yang mengidap virus HIV ini, tidak diperbolehkan menyusui bayinya secara langsung atau memberi ASI, lebih baik memberikan susu kaleng yang sudah ada resep dari dokter anak tersebut (Gallant, 2010: 25-26). Maka dengan demikian diharapkan sedini mungkin untuk menjaga dan memperhatikan kesehatannya supaya terhindar dari berbagai penyakit termasuk penyakit AIDS yang disebarkan oleh virus HIV. Seandainya tidak diperhatikan itu akan mengakibatkan kerusakan atau boroknya organ-organ tubuh manusia dan bisa menyebabkan kematian.

\section{Sumber Visual}

Untuk memvisualisasikan organ tubuh manusia dan virus HIV diperlukan pula Sumber visual adalah sumber atau data-data yang didapat dari lingkungan alam disekitar, atau diproleh dari buku-buku, majalah dan juga sumber didapat dari karya seni, misalnya seni kriya, lukis, patung dan lain lain. Terpenting bisa menunjang terwujudnya karya yang akan divisualkan. Adapun sumber visual yang dimaksud adalah sebagai berikut:

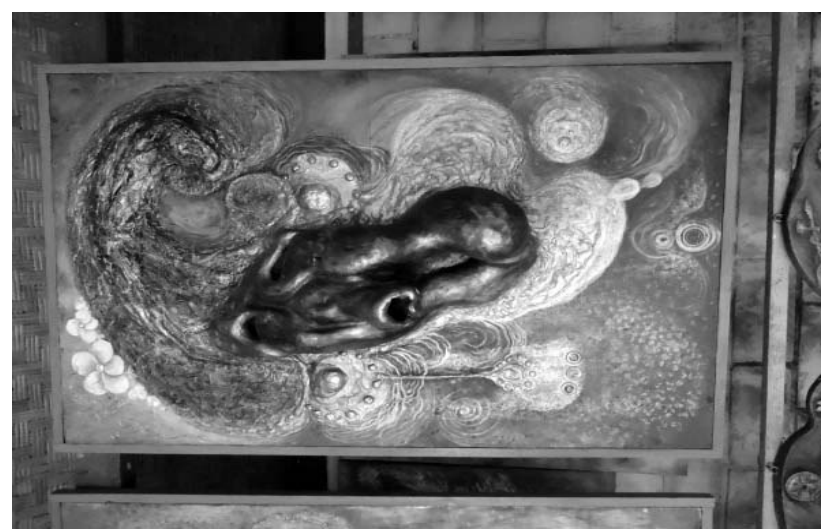

Gambar 3. Lingga Yoni

(Karya I Made Sukanta Wahyu)

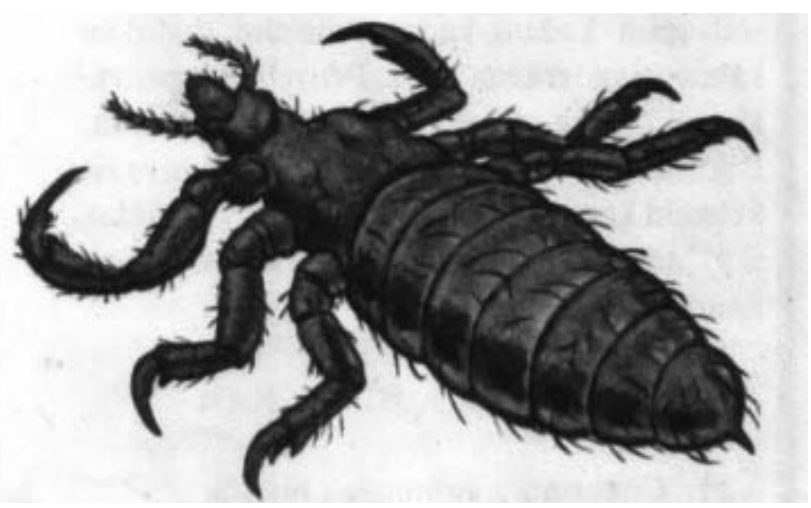

Gambar 4. Kutu Kepala

(Sumber: Shryock, 1982: 417)

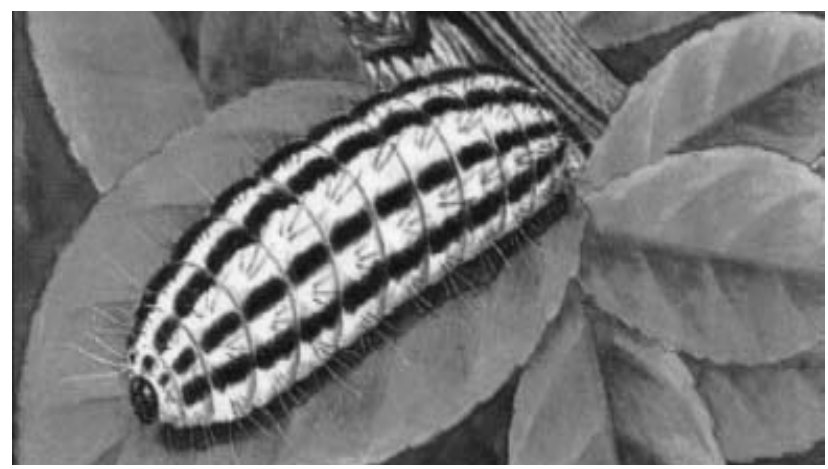

Gambar 5. Ulat Berbulu Kuning

(Sumber: Dunia Serangga, tt: 121) 


\section{Metode Penciptaan}

Metode merupakan cara sistematis dan terpikir secara baik untuk mencapai tujuan. Dalam penciptaan karya kriya seni tentu melalui metode penciptaan dan beberapa tahapan, atau cara yang harus dilalui oleh para pencipta. Tahapan tersebut harus terstruktur dan sedapat mungkin menggambarkan suatu proses penciptaan yang teratur dan rasional. Maka diperlukan pendekatan atau metode comparable yang sesuai dengan proses penciptaan yang dilakukannya, atau sesuai dengan ciptaannya. Proses penciptaan tersebut dapat dilakukan dengan tiga tahapan yang harus dilalui adalah eksplorasi, perancangan dan perwujudan (Gustami, 2007: 329). Namun dalam tiga tahapan tersebut, tentu dilalui oleh para pencipta mulai dari penelusuran, penggalian, pengumpulan data dan reprensi yang diikuti, serta mendeskripsikan masalah dan mencari solusi untuk jalan keluarnya. Sehingga menjadi dasar perancangan yang diinginkan. Perancangan tersebut terus dilakukan dengan mendisain atau membuat sket awal atau desain rancangan dan desain terpilih yang nantinya diwujudkan secara nyata, ke dalam suatu media sehingga terwujud karya seni yang diinginkan.

\section{A. Eksplorasi}

Dalam melakukan eksplorasi itu bertujuan untuk membuka kepekaan terhadap apa yang akan dilihat, dirasakan dan merekamnya dalam benak (pikiran). Segala sesuatu yang menjadi intres akan mengendap dalam benak (pemikiran) kemudian dituangkan dalam media sehingga lahirlah karya seni. Dalam tahapan eksplorasi ini ada dua langkah yang perlu dilakukan bagi pencipta yaitu eksplorasi internal dan eksternal. Eksplorasi internal itu menyangkut tentang ide, pengalaman, kesetaraan, pemahaman dan yang lainnya. Tahap ini dilakukan dengan identifikasi dan perumusan masalah dengan cara penyelusuran, penggalian, pengumpulan data dan refrensi, untuk mendapatkan persoalan yang akan diangkat dalam penciptaan karya seni (Gustami, 2007: 329). Hal ini yang jelas digali yaitu tentang konsep, makna dan simbol yang di angkat dalam penciptaan nantinya. Sedangkan tahap eksplorasi eksternal, itu menyangkut tentang bentuk organ tubuh manusia dan virus HIV yang dapat menyebabkan penyakit AIDS.

\section{B. Perancangan}

Di dalam proses penciptaan karya kriya seni, perancangan sangat perlu diwujudkan dengan mengadakan eksperimen. Pencipta bereksperimen dengan membuat coretan-coretan spontan dalam mencari format, model dan bentuk yang dianggap cocok, serasi antara konsep dan objek visual. Semua itu digali agar menemukan bentuk, teknik, variasi isian, wujud karya yang akan ditampilkan. Eksperimen awal dilakukan dengan membuat sket-sket, desain-desain kecil yang merupakan pra desain untuk mencari desain yang diwujudkan. Desain-desain tadi kemudian dipilih, yang dianggap tepat dari bentuk, proporsi dan komposisi menjadi desain tetap terjadi, tetapi terus digali, dirubah sampai menemukan desain terbaik. Adapula desain seperti contoh di bawah ini.

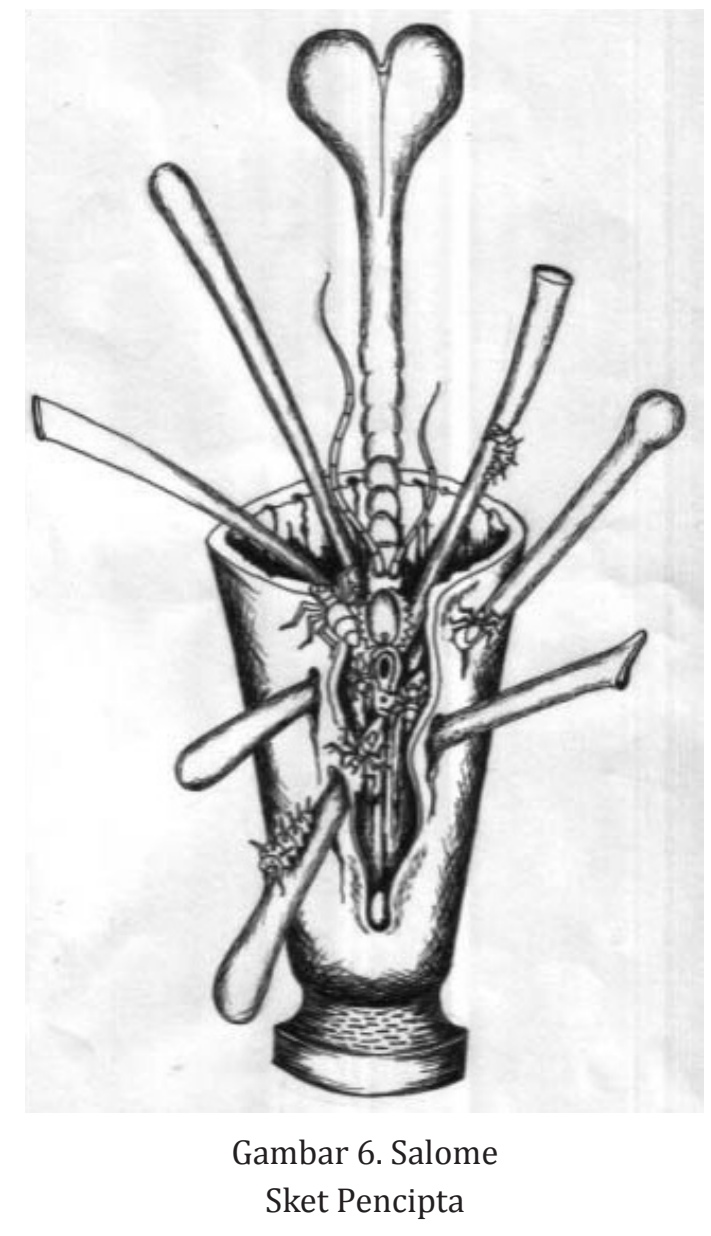




\section{Perwujudan}

Dalam tahap perwujudan, rancangan desain yang sudah dipilih kemudian dituangkan dalam media kayu, sesuai harapan untuk karya final. Pahatan spontan, halus dan kasar dalam bentuk tekstur dimunculkan untuk melahirkan kesan dinamis dalam karya. Pahatan itu dapat menampilkan karya yang harmonis.

Proses perwujudannya yaitu pertama, pembentukan secara global, mempergunakan mesin sensor merek Stihl, kode Ms 230, apabila bahan kayu masih berbentuk glondongan atau pembentukan dengan menggunakan mesin screollsaw, bila bahannya sudah berbentuk papan. Tahap pembentukan ini dilanjutkan dengan mempergunakan alat pahat. Kedua, pembuatan detail bentuk dijadikan pokus dalam karya. Pembuatan detail bentuk ini mempergunakan pahat, disesuaikan dengan bentuk-bentuk detail yang diinginkan. Baik penegasan garis, bidang datar, ruang, bentuk cekung, cembung dan tembus. Ketiga, pemasangan konstruksi dalam hal ini mempergunakan pahat apabila ada yang melubangi maupun pembuatan purusnya, kemudian ditempelkan dengan mempergunakan lem merek cianoakrilate (G). Tetapi dalam konstruksi ini ada juga mempergunakan mesin bor merek Bosch, kode Gsb 16, untuk melubangi kedua belah bidang yang ditempelkan dan di dalamnya diisi purus dengan mempergunakan bahan kayu, selanjutnya diisi lem dan ditempelkan keduanya. Ke empat, pengisian tekstur, ada dua yaitu tekstur nyata dan tekstur semu. Tekstur nyata adalah tekstur yang bisa diraba atau dirasakan lewat tangan maupun penglihatan yang merasakan adanya tekstur tersebut. Tekstur semu merupakan tekstur yang bisa dilihat gelap dan terang tidak bisa dirasakan dengan tangan. Kelima, tahap akhir, pengamplasan merupakan bagian tahap akhir yang diperlukan, bertujuan untuk membersihkan sisa pahatan-pahatan, menghaluskan dan memperjelas serat kayu. Kemudian proses akhir diwarna secara transparan untuk menunjukkan serat kayu. Diisi semir merek kiwi dengan tujuan untuk mengkilapkan karya dan kesan semir seolah-olah menyatu dengan kayu. Adapun poto karya kriya seni diperlihatkan sebagai berikut.

\section{Hasil Ciptaan}

Hasil ciptaan merupakan hasil akhir dari apa yang bisa diciptakan atau diwujudkan lewat karya seni sesuai dengan keinginan. Adapun hasil ciptaan itu adalah sebagai berikut.

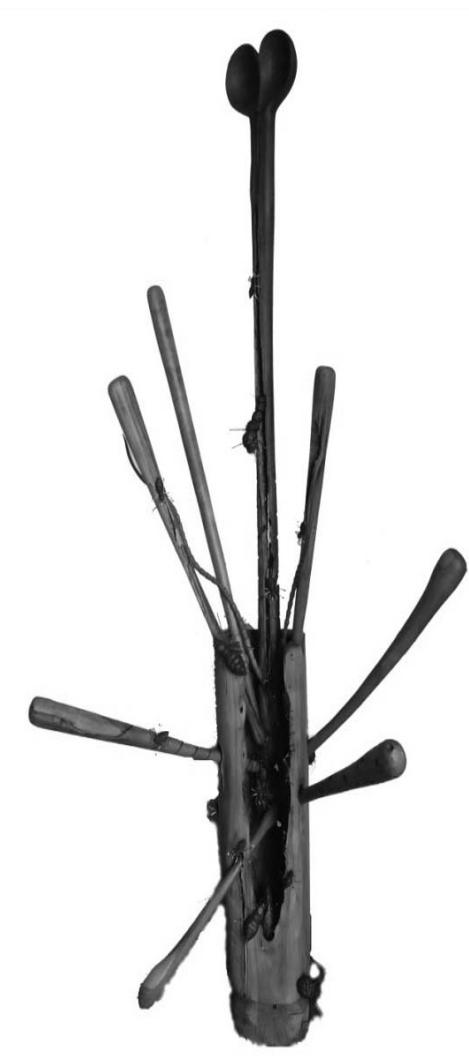

Gambar 7. Salome

Bahan: Kayu, Tembaga dan Aluminium Ukuran: 57 x 98 x $180 \mathrm{~cm}$

Tahun: 2013

\section{Deskrifsi Karya}

Karya ini berjudul, Salome" merupakan karya yang berbentuk tiga dimensional, dapat dilihat dari segala sudut, baik tampak depan, samping dan atas. Karya ini berdiri di atas pustek dengan harapan dapat mendukung karya, dari segi komposisi, keseimbangan dan keharmonisan. Adapun teknik yang dilakukan pencipta yaitu teknik ukir dan konstruksi guna memperlihatkan craftsmenship yang tinggi, serta menampilkan karakter dan simbol yang terkandung di dalamnya. Karya ini mempergunakan bahan kayu yaitu kayu jati, serta memakai bahan aplikasi mis- 
alnya tembaga dan aluminium.

Dalam karya menampilkan garis lurus dan lengkung yang menimbulkan kesan irama sehingga karya kelihatan dinamis, harmoni dan memunculkan tekstur nyata yang dijadikan elemen pokok maupun pendukungnya. Karya berjudul, Salome" memperlihatkan bentuk penis dan vagina. Penis itu jumblahnya delapan buah, yang seolah-olah melakukan hubungan seksual, merebut kemaluan perempuan. Penis yang letaknya ditengah-tengah menghadap ke atas, berisi tanduk, badannya borok berisi virus. Begitu pula penis yang letaknya disebelah kiri maupun kanan, yang sama-sama berisi virus. Karya ini difinishing menggunakan cat air hanya pada bagian kemaluan perempuan dan yang lainnya diisi semir tujuannya untuk memperlihatkan serat kayunya.

Judul ini mengisiaratkan bahwa dalam kehidupan manusia di dunia ini hanya memikirkan kesenangan dan kenikmatan sesaat, tidak memikirkan kesehatan. Semuanya itu dapat diperlihatkan dalam karya yang merebut kemaluan perempuan. Dengan melakukan hubungan seperti ini kemungkinan besar akan menyebabkan suatu penyakit salah satunya yaitu penyakit AIDS, yang disebarkan oleh virus HIV. Serangga seperti kutu manusia, ini dapat dijadikan sebagai simbol virus HIV. Virus ini dapat menyebar selain melalui hubungan seksual, juga dapat menyebar lewat senjata tajam dan runcing melalui darah.

\section{Kesimpulan Dan Saran-Saran}

Berdasarkan uraian sebelumnya dapat disimpulkan bahwa dampak pergaulan bebas sebagai sumber ide penciptaan kriya seni, merupakan kejadian yang lebih banyak menekankan pada kesenangan, kenikmatan dan kemewahan. Hal tersebut terlihat dikalangan remaja yang cenderung mengarah pada seksual. Masa remaja merupakan usia produktif, kesempatan menuntut ilmu dan sifatnya positif. Tetapi kenyataannya banyak dilakukan dengan bergantian, tanpa memikirkan masa depan dan kesehatan. Prilaku demikian dapat menimbulkan penyakit dalam tubuh termasuk organ-organ, yang disebabkan oleh virus dan mengakibatkan kematian. Hal tersebut menarik untuk divisualisasikan dalam karya seni. Dalam perwujudan simbol tentang serangga misalnya ulat dan kutu manusia, merupakan hal yang tepat antara konsep dan karya yang diciptakan. Dengan mengambil bentuk organ tubuh manusia dan virus HIV yang menyebabkan penyakit AIDS, sebagai simbol kehidupan dan kejahatan. Divisualisasikan dalam media kayu dengan teknik ukir dan konstruksi yang tinggi. Proses akhir difinishing menggunakan warna dan terakhir diisi semir merek kiwi. Hasil karya seni berbentuk tiga dimensional dan dipajang ditengah-tengah ruangan.

\section{DAFTAR PUSTAKA}

Budiyono, Setiadi. 2011. Anatomi Tubuh Manusia. Cetakan Kedua. Bekasi Jawa Barat: Laskar Aksara. Drijarkara. 1990. Filsafat Manusia. Cetakan Kesembilan. Yogyakarta: Kanisius.

Fajri, Em Zul. Ratu Aprilia Senja. tt. Kamus Lengkap Bahasa Indonesia. Jakarta: Difa Publisher.

Gallant, Joel. 2010. Seratus Tanya Jawab Mengenai HIV dan AIDS. Cetakan Pertama Jakarta: PT Indeks.

Gustami SP. 2007. Butir-Butir Mutiara Estetika. Yogyakarta: Prasista.

Nursalam. Ninuk Dian Kurniawati. 2007. Asuhan Keperawatan pada Pasien Terinfeksi HIV/ AIDS. Jakarta: Salemba Medika.

Setiadi. 2007. Anatomi \& Fisiologi Manusia. Cetakan Pertama. Yogyakarta: Graha Ilmu.

Shryock, Harold M.D. 1982. Penuntun Perawatan dan Pengobatan Modern. Bandung: Indonesia Publishing House.

Anonim. tt. Dunia Serangga. Jakarta: Tira Pustaka. 